\title{
Pollution control: how an EEC directive muddied the waters
}

Britain and the EEC have been arguing for many years about the best way of controlling pollution. The conflict arose not because anyone disagreed that certain substances should be controlled but because the EEC wanted to lay down a blanket standard of emission into rivers from sewers and factories.

Britain argued that this was wasteful and inefficient because it took no account of the use of a particular river nor its capacity to dilute and disperse waste materials.

Britain wanted local controls, based on local conditions and local usage, as long as there was no risk to human health or animal life.

Eventually, in December 1975, the EEC Council of Ministers compromised and agreed to let the British control pollution in their own way. But now new directives have been issued from Brussels concerning the control of specific substances in water and they put a question mark over that 1975 agreement

\section{Extracts from a speech by Lord Ashby (right) to the House of Lords in London last week}

6 The first of the 'drin' Directives sets a limit for the emission of dieldrin. It is 60 parts per billion in the waste water discharged into the river. Clearly, the Commission considers that this is going to be a little dificult because it allows factories time to build treatment plant. The limit is not to become binding until 1986, six years ahead. The second Directive offers the other option, the one we asked for: an environmental quality objective for the river into which the wastes are discharged. The level proposed for this is 0.005 parts per billion. Unlike the first option, this level has to be reached in two years' time, which gives the impression that it is an easier option.

These requirements make a nonsense of the options agreed by the Council of Ministers after great pressure from the British Government in 1975. First, the two options are mutually contradictory and inconsistent. Suppose we complied with the first Directive. Suppose we reduced emissions to 60 parts per billion in the Calder River (the river most affected in the UK). Would this result in an environmental quality objective of 0.005 parts per billion? It certainly would not. After doing a little arithmetic, which is fully within the capacity of the staff of the Commission, it has been found that it would need a flow of one hundred times that of the Calder at its minimum value in order to produce that degree of dilution; in fact many times the flow of the Thames at Teddington.

So the two proposed standards simply do not match. This could either be a deliberate soft option for those member states that want to choose an emission standard or it is a sign that the scientific basis for these figures is very suspect. That is not the only difficulty. The standard of 0.005 parts per billion is inconsistent with two other Directives which have already been published by the Commission and agreed by the Council on their own definition of pollution. For instance, the Commission has already agreed in principle that the level of dieldrin in water to be used for human consumption is to be not more than 0.1 part per billion - that is, 20 times higher than the level proposed in this Directive - so the limit has obviously not been set to make the water safe to drink.

What about the fish? Three years ago the Commission published its own water standards for fish. In this Directive, which has now been adopted, pesticides are not included at all. However, it is possible to calculate what the safe level will be because it is known that for a coarse fish like the roach - and we are talking about coarse river fishery in the Calder — about two parts per billion is the beginning threshold value for damage, and the level of dieldrin in the Calder varies a good deal; but it is in the region of 0.1 part per billion, that is one-twentieth of the danger level.

So on two counts, both falling in the definition of pollution by the Commission itself - human health and the health of fish - the environment quality objective proposed just does not make sense. There remains a very important fact, that the fish and other living things accumulate dieldrin from water, and they concentrate it enormously in their own tissues. If people then eat the fish they might be at danger. Experts are reluctant to commit themselves to precise figures for the amount of dieldrin which fish and other living things will accumulate from the environment. However, it is a general consensus that it is a multiple of 10,000 of the concentrations outside.

If the Calder carried trout, salmon or eels - which it does not because of pollutants other than dieldrin - then there would be an indubitable case for monitoring the dieldrin level of the fish. Then consent levels on the river could be imposed which would guarantee that the acceptable daily intake, if people ate the fish every day would be safe. This is exactly what is being done all the time in Britain in waters where fish are eaten. But coarse fish are not eaten in Britain, and the present use to which that stretch of water is put does not justify such drastic lowering of the dieldrin level either - to come back to the Commission's own definition - on grounds of hazards to human health or on grounds of harm to living resources.

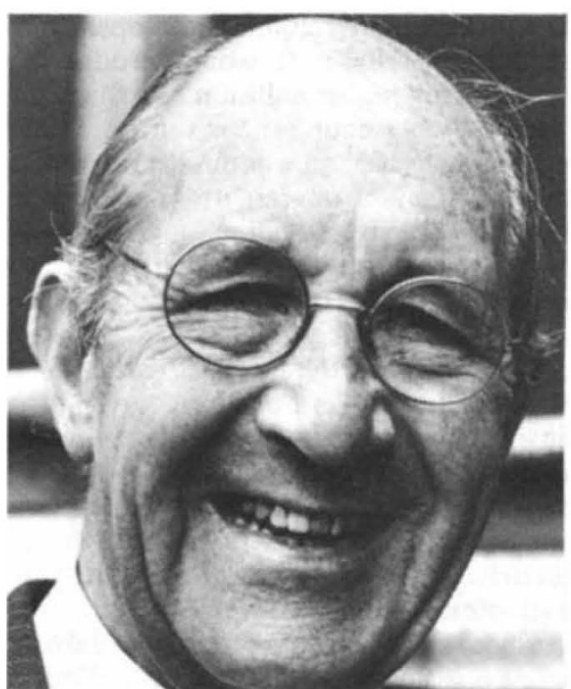

Finally, there is a practical difficulty about settling a standard of 0.005 parts per billion which the drafters of the Directive do not seem to have noted. The waters which fall into a river from a mothproofing plant such as those on the river Calder (these plants produce the dieldrin) contain many impurities. If one wants to analyse the water containing those impurities for the concentrations of dieldrin, one simply cannot detect levels lower than about 0.01 parts per billion, so the level proposed in the Directive is one which could not in fact be measured, except by most refined and difficult research techniques. So the idea of monitoring concentrations of that level as a routine matter simply is not on.

These are the reason why I think it is not an exaggeration to say that "nonsense" is the word that has to be used for this option offered to the nation states in the Community which prefer to take environmental quality objectives rather than emission standards. How did the Commission come across this figure? The Directive states that the figure was reached "after consulting a group of national experts", and also on the basis of a study made by consultants in the Agricultural University of Wageningen in Holland. But as with previous Directives about the environment, scientific evidence for the decision is not given and the consultants' report is not published.

However, I have talked with the British experts in this matter and their view is clear from what I have already explained to your Lordships. I have managed to see a copy of the consultants' report. Again for the record, I should like to read the conclusion of that report: "This leads to the rather disappointing conclusion that most toxicological studies made so far with the aim to assess the environmental hazards of aldrin, dieldrin and endrin ... have been inadequate in the sense that for the aquatic environment no practical environmental threshold levels can be derived from thier results",

The Commission then concludes, based on that conclusion, without providing any of the consultants' data, that the 
environmental quality should be set at a level which is inconsistent with two other Commission Directives, unjustified on grounds of safety to human beings or wildlife, and below the limits detectable by routine analyses. As one of our witnesses put it, data appeared to have been plucked out of the air using a concentration factor much higher than the one thought to be reasonable by British experts.

We all want to reach amicable agreement with the Commission over an environmental policy for the Community, and we all agree that dieldrin is a harmful substance which ought be phased out as soon as satisfactory alternatives are found. But we see no prospect of amicable agreement unless the Commission can be persuaded to adopt two simple principles when it prepares its Directives.

- The first principle is to abide by a declaration of the Council of Ministers made in 1973 about the environment. This declaration is the only authority for having a European environmental policy at all. It states that protection of the environment should be achieved "at the lowest cost to the Community" and that in setting quality objectives "proper account must be taken of the specific characteristics of the regions in question"'.

This means the deployment of our limited resources in places where they could be most cost-effective. It means that we should have different environmental qualities for rivers, depending on whether they carry game fish, coarse fish or no fish at all. Following this policy in Britain over the last 20 years, we have increased the amount of unpolluted rivers by about 4,500 kilometres and we have diminished the amount of badly polluted rivers by about 1,500 kilometres. I doubt whether any other member state in the Community can match that record. A doctrinaire pursuit of uniform emission standards would wreck this policy.

-The second principle is to insist on free and candid disclosure of the scientific evidence on which Directives are based. It simply is not good enough for the Commission to say, "After consulting a group of experts, we set such and such standards"'. The Select Committee has now got plenty of evidence that the experts' advice is not always taken. To comply with some of these Directives - for instance, that proposed for fish - would put member states to enormous expense and to expect them to incur this enormous expense without even seeing the data on which the standards are based is, I suggest, an intolerable situation. I am afraid it is true - and we regret it - that there will be perpetual wrangling over environmental policy in the Community until this freedom of information is secured.

Compared with the Common Agricultural Policy, the Commission's environmental policy for Europe may well be a small matter. But it is a perpetual source of irritation.

\section{UK to tighten asbestos controls}

TIGHTER safety standards for asbestos are proposed in a report published last week by the UK Health and Safety Commission (HSC). The report, prepared by the commission's Advisory Commission of Asbestos (ACA) makes proposals, which according to the committee's chairman $\mathrm{Mr}$ Bill Simpson would, if they became law, "mean that Britain would share with Sweden the most stringent asbestos rules of any country".

The report recommends that the standards currently in operation regulating asbestos fibre concentration should be halved to $1 \mathrm{fb} \mathrm{ml}^{-1}$ for chrysotile (white asbestos); reduced four-fold to $0.5 \mathrm{fb} \mathrm{ml}^{-1}$ for amosite (brown); and that a statutory ban be placed on crocidolite (blue) in the UK. In addition, until such fibres as crocidolite are replaced, the standard for its removal should remain at the present 0.2 $\mathrm{fb} \mathrm{ml}^{-1}$.

It is proposed that the new standards should take effect from 1 December 1980 and that in future they should be referred to as "control limits" rather than "hygiene standards", the latter definition suggesting an asbestos concentration below which exposure is safe.

Simpson firmly believes that the new standards will reduce the incidents of asbestos-related diseases in future. It is the report's view that exposure to one fibre per mille of chrysotile daily over a period of 50 years will cause an increased mortality rate of 0.02 to 1.25 per cent. This prediction is based on the results of the only three surveys - two North American, one British - which provided adequate dose/response data. Calculations of mortality rates based on these results have th sir problems, however, as the report readily admits. Much of the data in these surveys on asbestos concentration was obtained by measuring particle counts, a far less precise method than the normal practice of counting fibres.

As far as the public is concerned, the report concludes that there is no quantitative evidence of risk from overexposure to asbestos dust. The report says that despite the fact that there is a high proportion of individuals, especially in urban areas, with asbestos fibres in their lungs, there has been no general reporting of asbestosis. Accordingly the report suggests that "there may be a threshold level" below which asbestosis is not detectable.

This, however, does not hold true for the carcinogenic properties of asbestos. The report states baldly that there is "no evidence" for the existence of a threshold below which lung cancer or mesothelioma - of the pleura or the peritoneum - will not occur. It is the report's view, however, that crocidolite is consistantly more dangerous than chrysotile and should be treated accordingly. Swedish and Dutch regulatory authorities agree.

The report acknowledges that all forms of asbestos will cause lung cancer. In numerical terms, lung cancer is the great killer but the report says "included in this excess mortality from lung cancer is a substantial element due to the syenergistic action of tobacco with asbestos, which cannot therefore properly be attibuted to the effect of asbestos alone"'. The asbestos industry has always made much of this synergism to play down the role of asbestos in the aetiology of lung cancer.

On the quesion of death due to mesothelioma, the report is unequivocal; the majority of these are due to exposure by chrysotile. Death from mesothelioma reported in American asbestos workers (the report says) are attibutable to exposure to both amosite and chrysotile and not to chrysotile alone.

Deaths from mesothelioma in the UK doubled between 1967 and 1976 currently standing at some 320 per annum - and the report expects the number to increase before the peak is reached.

The asbestos industry makes no pretence of being pleased about the December 1980 deadline for enforcing the 0.5 fibre per mille limit for amosite. Mr S D Hardie of Turner and Newall and an advisory committee member says that the deadline is too tight. He insists that working to 0.5 fibres per mille is pushing the technology to its limit. The industry, he says, can work to one fibre per mille of chrysotile but, as far as the 0.5 fibre per mille for amosite is concerned, Hardie says he could not "put his hand on his heart and say to the work force that it is not being exceeded"'.

Criticism that the advisory committee has been too sensitive to the needs of industry has been voiced by the Society for the Prevention of Asbestos and Industrial Diseases. Mr Max Madden, a trustee of the society and former Labour MP for Sowerby - a constituency which includes the ACRE Mill asbestos factory at Hebden Bridge - was frank about the pressure on the advisory committee. In his view, the committee had been subjected to considerable propaganda from the industry and some of it had succeeded. Anticipating criticism of its report, ACA chairman Bill Simpson emphasised that the control limits are not a "once and for all" exercise. New evidence will be constantly reviewed, and every encouragement was being given to the development of safe asbestos substitutes.

Comments on the report are invited and should be submitted by 31 January 1980 .

Alastair Hay

Asbestos Volume 1, final report of the Advisory Committee, $£ 5(p+p)$.

Volume 2, papers prepared by the Advisory Committee $f 5(p+p)$ available from HMSO. 